\title{
DIAGNOSIS DAN TATALAKSANA KOMPREHENSIF OSTEOARTRITIS
}

\author{
Winangun \\ Fakultas Kedokteran Universitas Islam Al-Azhar \\ Jl. Unizar No. 20 Turida Mataram \\ Email:winscie88@gmail.com
}

\begin{abstract}
ABSTRAK
Osteoartritis merupakan gangguan persedian yang ditandai dengan adanya nyeri dan kekakuan sendi yang biasanya banyak terjadi pada usia lanjut. Osteoartritis adalah penyakit sendi degeneratif dan inflamasi yang ditandai dengan perubahan patologik pada seluruh struktur sendi. Perubahan patologis yang terjadi meliputi hilangnya tulang rawan sendi hialin, diikuti penebalan dan sklerosis tulang subkondral, pertumbuhan osteofit pada tepi sendi, teregangnya kapsul sendi, sinovitis ringan dan kelemahan otot yang menyokong sendi (Felson, 2012). Berdasar data Center for Disease Control and Prevention (CDC) 1, angka kejadian osteoartritis pada usia > 25 tahun sebanyak 13,9\% dan pada usia > 65 tahun sebanyak 33,6\%. Osteoartritis (OA) merupakan penyakit yang paling banyak menyebabkan kecacatan pada orang tua. OA menduduki peringkat kelima sebagai penyebab kecacatan di seluruh penduduk di negara-negara berpenghasilan tinggi, dan penyebab tertinggi kesembilan di Negara berpenghasilan rendah dan menengah.
\end{abstract}

Kata Kunci: Osteoartritis, Degeneratif dan Inflamasi, Patologik, CDC.

\section{PENDAHULUAN}

Osteoartritis (OA) merupakan penyakit yang paling banyak menyebabkan kecacatan pada orang tua. OA menduduki peringkat kelima sebagai penyebab kecacatan di seluruh penduduk di negara-negara berpenghasilan tinggi, dan penyebab tertinggi kesembilan di negara berpenghasilan rendah dan menengah. Penyakit tersebut menyumbang sekitar $50 \%$ dari seluruh penyakit muskuloskeletal, yang merupakan kondisi terbesar dalam kelompok penyakit muskuloskeletal, selain rheumatoid arthritis dan osteoporosis (soeroso 2014,WHO, 2004). Osteoartritis merupakan suatu penyakit degenerasi sendi yang dipengaruhi oleh banyak faktor risiko seperti obesitas. OA juga memiliki beberapa faktor risiko lain, yaitu faktor usia, jenis kelamin, dan pekerjaan dengan aktivitas yang berat. Obesitas dapat meningkatkan beban biomekanik pada sendi lutut, panggul, dan sendi lainnya selama aktivitas, yang biasanya dikaitkan dengan pemicu timbulnya osteoartritis (Soeroso, 2006).Temuan radiografi OA lutut didapatkan kira-kira 30\% pada laki-laki dan pada wanita yang memiliki usia lebih dari 65 tahun. Sekitar $80 \%$ dari mereka yang menderita OA akan memiliki keterbatasan dalam bergerak, dan $25 \%$ tidak dapat melakukan pekerjaan berat dalam kehidupan sehari-harinya. Pada 10$15 \%$ orang yang berusia lebih dari 60 tahun menderita beberapa derajat OA. Prevalensi OA lutut secara radiologis di Indonesia cukup tinggi, yaitu mencapai $15,5 \%$ pada pria, dan $12,7 \%$ pada wanita (Amin Z 2015,WHO, 2004). 
The Subcommittee on Osteoarthritis of the American College of Rheumatology Diagnostic and Therapeutic Criteria Committee mendefinisikan osteoartritis sebagai sebuah kondisi heterogen yang menyebabkan gejala pada sendi dan tanda-tanda yang berhubungan dengan integritas kerusakan tulang rawan artikular. Secara klinis, kondisi ini ditandai dengan nyeri sendi, keterbatasan gerak, krepitus, kadang efusi, dan peradangan lokal (Deborah Symmons, 2000). Studi kesehatan masyarakat University College London menyimpulkan bahwa obesitas dapat meningkatkan risiko terjadinya osteoartritis hingga empat kali lipat pada pria dan tujuh kali lipat pada wanita. Fakta tersebut menyimpulkan bahwa obesitas merupakan suatu faktor risiko terjadinya osteoartritis, terutama pada sendi lutut (Arthritis Research Campaign, 2009). Di Indonesia, pada tahun 2006, penderita osteoartritis mencapai $5 \%$ pada usia di bawah 40 tahun, 30\% pada usia 40-60 tahun, dan 65\% pada usia di atas 60 tahun. Untuk OA genu prevalensinya di Indonesia juga cukup tinggi yaitu mencapai $15,5 \%$ pada laki-laki dan $12,7 \%$ pada perempuan dari seluruh penderita osteoartritis (Soeroso, 2014). Di Provinsi NTB, 33,6\% penduduk mengalami gangguan persendian termasuk osteoartritis, dan angka ini lebih tinggi dari prevalensi Nasional yaitu 22,6\%. Gangguan pada persendian ini tertinggi dijumpai di Kabupaten Lombok Barat dan terendah di Kota Mataram (13,5\%). Sedangkan berdasarkan laporan data kesakitan tahun 2014 prevalensi penyakit pada sistem otot dan jaringan pengikat termasuk osteoartritis mencapai 77.541 penderita dan pada tahun 2015 prevalensinya meningkat menjadi 122.737 penderita (Riskesdas, 2007).

\section{OSTEOARTRITIS}

Adalah penyakit sendi Degeneratif dan Inflamasi yang ditandai dengan perubahan patologik pada seluruh struktur sendi. Perubahan patologis yang terjadi meliputi hilangnya tulang rawan sendi hialin, diikuti penebalan dan sklerosis tulang subkondral, pertumbuhan osteofit pada tepi sendi, teregangnya kapsul sendi, sinovitis ringan dan kelemahan otot yang menyokong sendi karena kegagalan perbaikan kerusakan sendi yang disebabkan oleh stress mekanik yang berlebih. (Felson, 2012,soeroso 2015 ) atau Osteoartritis (OA) adalah gangguan sendi yang bersifat kronis, yang ditandai dengan adanya degenerasi tulang rawan sendi, hipertrofi pada tepi tulang, dan perubahan pada membran sinovial. Gangguan ini disertai dengan nyeri, biasanya setelah aktivitas berkepanjangan, dan kekakuan, 
khususnya pada pagi hari atau setelah inaktivitas (Dorland, 2010).

\section{ETIOLOGI}

Berdasarkan etiopatogenesisnya, OA dibedakan menjadi dua yaitu osteoartritis primer dan osteoartritis sekunder. Osteoartritis primer disebut juga osteoartritis idiopatik yaitu osteoartritis yang kausanya tidak diketahui dan tidak ada hubungannya dengan penyakit sistemik maupun proses perubahan lokal pada sendi. Sedangkan osteoartritis sekunder adalah osteoartritis yang didasari oleh adanya kelainan endokrin (seperti acromegaly, hyperparathyroidisme dan hyperuricemia), inflamasi, posttraumatik, metabolik (seperti rickets, hemochromatis, chondrocalcinosis, dan ochronosis), kelainan pertumbuhan, herediter, jejas mikro dan makro serta imobilisasi yang terlalu lama (Joern, 2010 \& Sudoyo. A.W, 2006).Defek primer pada osteoartritis idiopatik maupun osteoartritis sekunder adalah hilangnya kartilago sendi akibat perubahan fungsional kondrosit (sel-sel yang bertanggung jawab atas pembentukan proteoglikan, yaitu glikoprotein yang bekerja sebagai bahan seperti semen dalam tulang rawan dan kolagen) (Kowalak J.P, 2011). OA merupakan penyakit gangguan homeostasis metabolisme kartilago dengan kerusakan struktur proteoglikan kartilago yang penyebabnya belum jelas diketahui (Soeroso 2014,Sudoyo. A.W, 2006).

\section{EPIDEMIOLOGI}

Osteoartritis merupakan penyakit sendi degeneratif dengan etiologi dan patogenesis yang belum jelas. Pada umumnya penderita osteoartritis berusia di atas 40 tahun dan populasi bertambah berdasarkan peningkatan usia (Felson, 2008).Osteoartritis merupakan golongan penyakit sendi yang paling sering menimbulkan gangguan sendi, dan menduduki urutan pertama baik yang pernah dilaporkan di Indonesia maupun di luar negeri. Dari sekian banyak sendi yang dapat terserang $\mathrm{OA}$, lutut merupakan sendi yang paling sering terserang. Osteoartritis lutut merupakan penyebab utama rasa sakit dan ketidakmampuan beraktivitas dibandingkan dengan OA pada sendi lainnya (Maharani, 2007).

Penelitian epidemiologi dari Joern et al (2010) menemukan bahwa orang dengan kelompok umur 60-64 tahun yang menderita OA sebanyak 22\%. Pada pria dengan kelompok umur yang sama, dijumpai $23 \%$ menderita osteoartritis pada lutut kanan, sementara 16,3\% sisanya didapati menderita osteoartritis pada lutut kiri. Berbeda halnya pada wanita yang terdistribusi merata, dengan insiden osteoartritis pada lutut kanan 
sebanyak $24,2 \%$ dan pada lutut kiri sebanyak $24,7 \%$ dan di beberapa negara eropa sekitar 18-25\%laki laki dan 24-40 \% wanita antara usia 60-79 tahun pada sekitar seratus juta penderita OA lutut.(Joern, 2010).

\section{GEJALA KLINIS}

Pasien OA biasanya berusia lebih dari 40 tahun dan osteoartritis lutut lebih banyak terjadi pada penderita dengan kelebihan berat badan. Pada umumnya, pasien osteoartritis mengatakan bahwa keluhan-keluhan yang dirasakannya telah berlangsung lama, tetapi berkembang secara perlahan. Berikut adalah keluhan yang dapat dijumpai pada pasien osteoartritis :

\section{Nyeri Sendi}

Keluhan ini merupakan keluhan utama pasien. Nyeri biasanya bertambah dengan gerakan dan sedikit berkurang dengan istirahat. Perubahan ini dapat ditemukan meski osteoartritis masih tergolong dini (secara radiologis). Umumnya rasa nyeri tersebut akan semakin bertambah berat sampai sendi hanya bisa digoyangkan dan menjadi kontraktur, hambatan gerak dapat konsentris (seluruh arah gerakan) maupun eksentris (salah satu arah gerakan saja) (Soeroso, 2014).Berdasarkan hasil Magnetic Resonance Imaging (MRI), didapat bahwa sumber dari nyeri yang timbul diduga berasal dari peradangan sendi (sinovitis), efusi sendi, dan edema sumsum tulang. Osteofit merupakan salah satu penyebab timbulnya nyeri. Ketika osteofit tumbuh, inervasi neurovaskular menembusi bagian dasar tulang hingga ke kartilago dan menuju ke osteofit yang sedang berkembang. Hal ini akan menimbulkan nyeri (Felson, 2008).

\section{Hambatan Gerakan Sendi}

Gangguan ini biasanya semakin bertambah berat secara perlahan sejalan dengan pertambahan rasa nyeri. Gangguan pergerakan pada sendi disebabkan oleh adanya fibrosis pada kapsul, osteofit atau iregularitas permukaan sendi (Soeroso, 2014).

\section{Kaku Pagi Hari}

Rasa kaku pada sendi dapat timbul setelah pasien berdiam diri atau tidak melakukan banyak gerakan, seperti duduk di kursi atau mobil dalam waktu yang cukup lama, bahkan setelah bangun tidur di pagi hari.

\section{Krepitasi atau rasa gemeretak dapat timbul pada sendi yang sakit}

Gejala ini umum dijumpai pada pasien osteoartritis lutut. Pada awalnya hanya berupa perasaan akan adanya sesuatu yang patah atau remuk .

\section{Perubahan Bentuk Sendi (Deformitas)}

Perubahan bentuk sendi ditemukan akibat kontraktur kapsul serta instabilitas sendi karena kerusakan pada tulang rawan sendi

\section{Pembengkakan Sendi Yang Asimetris}


Pembengkakan sendi yang dapat timbul dikarenakan terjadi efusi pada sendi yang biasanya tidak banyak $(<100$ cc) atau karena adanya osteofit, sehingga bentuk permukaan sendi berubah .

\section{Tanda - Tanda Peradangan}

Adanya peradangan pada sendi (nyeri tekan, gangguan gerak, rasa hangat yang merata, dan warna kemerahan) karena adanya sinovitis. Biasanya tanda ini tidak menonjol dan timbul pada perkembangan penyakit yang lebih jauh. Gejala ini sering dijumpai pada osteoartritis lutut .Perubahan gaya berjalan.Gejala ini dapat mengganggu kemandirian pasien osteoartritis, terlebih pada pasien lanjut usia. Keadaan ini selalu berhubungan dengan nyeri, karena menjadi tumpuan berat badan. Perubahan gaya berjalan terutama terjadi pada osteoartritis lutut.

\section{FAKTOR RISIKO}

Harus diingat bahwa masingmasing sendi mempunyai beban biomekanik, dan persentase gangguan yang berbeda, sehingga peran faktorfaktor risiko tersebut untuk masingmasing OA tertentu berbeda. Kegemukan, faktor genetik dan jenis kelamin adalah faktor risiko umum yang penting (Yusuf, 2012).

\section{Umur}

Dari semua faktor risiko untuk timbulnya OA, faktor usia adalah yang terkuat. Prevalensi dan beratnya OA semakin meningkat dengan bertambahnya umur. OA hampir tidak pernah pada anak-anak, jarang pada umur di bawah 40 tahun dan sering pada umur di atas 60 tahun. Akan tetapi harus diingat bahwa OA bukan akibat menua saja. Perubahan tulang rawan sendi pada usia lanjut berbeda dengan perubahan pada OA.

\section{Jenis Kelamin}

Wanita lebih sering terkena OA lutut dan OA sendi lainnya, dan lelaki lebih sering terkena OA paha, pergelangan tangan dan leher. Secara keseluruhan, di bawah 45 tahun frekuensi OA kurang lebih sama pada laki-laki dan wanita, tetapi di atas 50 tahun (setelah menopause) frekuensi OA lebih banyak pada wanita daripada pria. Hal ini menunjukkan adanya peran hormonal pada patogenesis OA.

\section{Suku Bangsa}

Prevalensi dan pola terkenanya sendi pada OA nampaknya terdapat perbedaan diantara masing-masing suku bangsa. Misalnya OA paha lebih jarang diantara orang-orang kulit hitam dan Asia daripada Kaukasia, OA lebih sering dijumpai pada orang-orang Amerika asli (Indian) dari pada orang-orang kulit putih. Hal ini mungkin berkaitan dengan perbedaan cara hidup maupun perbedaan pada frekuensi kelainan kongenital dan pertumbuhan.

\section{Genetik}


Faktor herediter juga berperan pada timbulnya OA, misalnya pada seorang wanita dengan ibu yang mengalami OA pada sendi-sendi interfalang distal (nodus Herbenden) akan mengalami 3 kali lebih sering OA pada sendi-sendi tersebut, dibandingkan dengan seorang wanita dengan ibu tanpa OA tersebut. Adanya mutasi dalam gen prokolagen II atau gengen struktural lain untuk unsur-unsur tulang rawan sendi seperti kolagen tipe IX dan XII, protein pengikat atau proteoglikan dikatakan berperan dalam timbulnya kecenderungan familial pada OA tertentu.( Soeroso 2014).

\section{Kegemukan dan Penyakit Metabolik}

Berat badan yang berlebih nyata berkaitan dengan meningkatnya risiko untuk timbulnya OA baik pada wanita maupun pada pria. Kegemukan ternyata tidak hanya berkaitan dengan OA pada sendi yang menanggung beban, tapi juga pada OA sendi lain. Di samping faktor mekanis (karena meningkatnya beban mekanis), diduga terdapat faktor lain (metabolik) yang berperan pada timbulnya OA. Pasien-pasien OA ternyata mempunyai risiko penyakit jantung koroner dan hipertensi yang lebih tinggi daripada orang-orang tanpa osteoartritis.

\section{Cedera Sendi, Pekerjaan, dan Olahraga}

Pekerjaan berat yang menggunakan seluruh sendi ataupun dengan pemakaian satu sendi yang terus menerus (misalnya tukang pahat, pemetik kapas) berkaitan dengan peningkatan risiko OA tertentu. Demikian juga cedera sendi dan olahraga berkaitan dengan risiko terjadinya OA yang lebih tinggi (misalnya robeknya meniscus, ketidakstabilan ligament).

\section{Kelainan Pertumbuhan}

Kelainan kongenital dan pertumbuhan (misalnya penyakit Perthes dan dislokasi kongenital paha) telah dikaitkan dengan timbulnya osteoartritis paha pada usia muda. Mekanisme ini juga diduga berperan pada lebih banyaknya OA pada laki-laki dan ras tertentu.Tingginya kepadatan tulang dikatakan dapat meningkatkan risiko timbulnya OA. Hal ini mungkin timbul karena tulang yang lebih padat (keras) tak membantu mengurangi benturan beban yang diterima oleh tulang rawan sendi. Akibatnya tulang rawan sendi menjadi lebih mudah robek (Soroso 2014,Sudoyo, A.W, 2006).

\section{PATOGENESIS OSTEOARTRITIS}

Osteoartritis selama ini dipandang sebagai akibat dari suatu proses degeneratif yang tidak dapat dihindari. Namun, hasil penelitian terbaru para pakar menyatakan bahwa OA ternyata merupakan penyakit gangguan homeostasis dari metabolisme kartilago dengan kerusakan struktur proteoglikan kartilago yang penyebabnya belum diketahui.Lutut adalah sendi besar yang paling sering terkena osteoartritis. Secara 
fisiologis, sendi lutut mendapat beban pada saat melakukan mobilisasi. Pada beberapa keadaan, pasien dengan cedera permukaan sendi, robekan meniscus, ketidakstabilan ligamen atau deformitas pinggul atau lutut, mengalami peningkatan risiko gangguan homeostasis metabolisme kartilago dengan kerusakan struktur proteoglikan kartilago sebagai jejas mekanis dan kimiawi. (Hadi S 2002, Soeroso 2015.)

Tanda-tanda fibrilasi kartilago yang khas, sklerosis tulang subkondral, dan pembentukan osteofit perifer, hal tersebut biasanya timbul pada kasus yang parah, permukaan sendi dapat kehilangan kartilago sama sekali dan tulang yang mendasari akhirnya dapat remuk. Kerusakan struktur kartilago menyebabkan kompresi saraf di sekitar sendi, penurunan fungsi sendi dalam melakukan mobilisasi fisik, sehingga dapat menimbulkan dampak psikologis. Osteoartritis terjadi sebagai hasil kombinasi antara degradasi rawan sendi, remodeling tulang, dan inflamasi cairan sendi. Osteoartritis terbentuk pada dua keadaan, yaitu (1) Sifat biometrial kartilago sendi dan tulang subkondral normal, tetapi terjadi beban berlebihan terhadap sendi sehingga jaringan rusak, atau (2) Beban yang ada secara fisiologis normal, tetapi sifat bahan kartilago atau tulang kurang baik (Denis Kasper et al, 2008).
Beberapa penelitian membuktikan bahwa tulang rawan (kartilago) sendi ternyata dapat melakukan perbaikan sendiri dimana kondrosit akan mengalami replikasi dan memproduksi matriks baru. Proses perbaikan ini dipengaruhi oleh faktor pertumbuhan seperti insulin-like growth factor (IGF-1), growth hormone, transforming growth factor $\beta$ (TGF- $\beta$ ) dan coloni stimulating factor (CSFs). Faktor pertumbuhan seperti IGF-1 memegang peranan penting dalam proses perbaikan tulang rawan sendi. Pada keadaan inflamasi, sel menjadi kurang sensitif terhadap efek IGF-1 (Soeroso 2014, Hadi S.2002 \& Yusuf, 2012).

$$
\text { Faktor pertumbuhan TGF- } B
$$
mempunyai efek multipel pada matriks kartilago, yaitu merangsang sintesis kolagen dan proteoglikan serta menekan stromelisin, yaitu enzim yang mendegradasi proteoglikan, meningkatkan produksi prostaglandin E2 (PGE2) dan melawan efek inhibisi sintesis PGE2. Hormon lain yang mempengaruhi sintesis komponen kartilago adalah testosterone, $\beta$ estradiol, platelet derivate growth factor (PDGF), fibroblast growth factor dan kalsitonin. Peningkatan degradasi kolagen akan mengubah keseimbangan metabolisme tulang rawan sendi. Kelebihan produk hasil degradasi matriks rawan sendi ini cenderung berakumulasi di sendi dan menghambat fungsi rawan sendi serta 
mengawali suatu respon imun yang menyebabkan inflamasi sendi. Pada rawan sendi pasien Osteoartritis juga terjadi proses peningkatan aktivitas fibrinogenik dan penurunan aktivitas fibrinolitik. Proses ini menyebabkan terjadinya penumpukan trombus dan komplek lipid pada pembuluh darah subkondral yang menyebabkan terjadinya iskemia dan nekrosis jaringan subkondral tersebut. Ini mengakibatkan dilepaskannya mediator kimiawi seperti prostaglandin dan interleukin yang selanjutnya menimbulkan Bone Angina lewat subkondral yang diketahui mengandung ujung saraf sensibel yang dapat menghantarkan rasa sakit. Sakit pada sendi juga diakibatkan oleh adanya osteofit yang menekan periosteum dan radiks saraf yang berasal dari medulla spinalis serta kenaikan tekanan intramedular akibat statis vena intramedular karena proses remodeling pada trabekula dan subkondrial (Soeroso 2014, Hadi S 2002).

Peran Makrofag di dalam cairan sendi juga penting, yaitu apabila dirangsang oleh jejas mekanik, material asing hasil nekrosis jaringan atau CSFs, akan memproduksi sitokin activator plasminogen (PA) yang disebut katabolin. Sitokin tersebut adalah $I L-1, I L-6, T N F-\alpha$ dan $\beta$, dan Interferon (IFN) $\alpha$ dan $\tau$. Sitokin-sitokin ini merangsang kondrosit melalui reseptor permukaan spesifik untuk memproduksi CSFs (Colony Stimulating Factors), yang sebaliknya akan mempengaruhi monosit dan Plasminogen Activator (PA) untuk mendegradasi tulang rawan sendi secara langsung. Pasien osteoartritis mempunyai kadar PA yang tinggi pada cairan sendinya. Sitokin ini juga mempercepat resorpsi matriks rawan sendi (Soeroso, 2014 \& Yusuf, 2012).

Interleukin-1 mempunyai efek multipel pada sel cairan sendi, yaitu meningkatkan sintesis enzim yang mendegradasi tulang rawan sendi yaitu stromelisin dan kolagenosa, menghambat proses sintesis dan perbaikan normal kondrosit. Kondrosit pasien osteoartritis mempunyai reseptor IL-1 dua kali lipat lebih banyak dibanding individu normal dan kondrosit sendiri dapat memproduksi IL-1 secara lokal, (Yusuf, 2012).

Faktor pertumbuhan dan sitokin tampaknya mempunyai pengaruh yang berlawanan selama perkembangan osteoartritis. Sitokin cenderung merangsang degradasi komponen matriks rawan sendi, sebaliknya faktor pertumbuhan merangsang terjadinya sintesis (Joern. M. 2010, Sudoyo. A.W, 2006).

Stimulasi dari sitokin terhadap cedera matriks adalah menstimulasi pergantian matriks, namun stimulaso IL-1 yang berlebih malah memicu proses degradasi matriks. TNF menginduksi 
kondrosit untuk mensintesis prostaglandin $(\mathrm{PG})$, oksida nitrit $(\mathrm{NO})$, dan protein lainnya yang memiliki efek terhadap sintesis dan degradasi matriks. TNF yang berlebihan mempercepat proses pembentukan tersebut. NO yang dihasilkan akan menghambat sintesis aggrekan dan meningkatkan proses pemecahan protein pada jaringan. Hal ini berlangsung pada proses awal timbulnya OA (Felson, 2008). Kartilago memiliki metabolisme yang lamban, dengan pergantian matriks yang lambat dan keseimbangan yang teratur antara sintesis dengan degradasi. Namun, pada fase awal perkembangan OA kartilago sendi memiliki metabolisme yang sangat aktif Pada proses timbulnya OA, kondrosit yang terstimulasi akan melepaskan aggrekan dan kolagen tipe dua yang tidak adekuat ke kartilago dan cairan sendi. Aggrekan pada kartilago akan sering habis serta jalinan-jalinan kolagen akan mudah mengendur.Kegagalan dari mekanisme pertahanan oleh komponen pertahanan sendi akan meningkatkan kemungkinan timbulnya OA pada sendi (Felson, 2008, Hadi S. 2002.).

\section{DIAGNOSIS}

Diagnosis Osteoartritis biasanya didasarkan pada gambaran klinis dan radiografi. Pada penderita osteoartritis, dilakukannya pemeriksaan radiografi pada sendi yang terkena sudah cukup untuk memberikan suatu gambaran diagnostik. Gambaran radiografi sendi yang mendukung diagnosis OA adalah (Viadamir, 2003) : Penyempitan celah sendi yang seringkali asimetris (lebih berat pada bagian yang menanggung beban), Peningkatan densitas (sklerosis) tulang subkondral, Osteofit pada pinggir sendi, Perubahan struktur anatomi sendi.

Kriteria diagnosis osteoartritis lutut menggunakan kriteria klasifikasi American College of rheumatology seperti tercantum pada tabel berikut :

Tabel 1.1. Kriteria klasifikasi Osteoartritis menurut American College of Rheumatology

\begin{tabular}{|c|c|c|}
\hline Klinik dan Laboratorik & Klinik dan Radiografik & Klinik \\
\hline $\begin{array}{l}\text { Nyeri lutut }+ \text { minimal } 5 \text { dari } \\
9 \text { kriteria berikut : } \\
\text { - Umur }>50 \text { tahun } \\
\text { - Kaku pagi }<30 \text { menit } \\
\text { - Krepitus } \\
\text { - Nyeri tekan } \\
\text { - Pembesaran tulang } \\
\text { - Tidak panas pada perabaan } \\
\text { - LED }<40 \mathrm{~mm} / \text { jam } \\
\text { - RF }<1: 40 \\
\text { - Analisis cairan sendi }\end{array}$ & $\begin{array}{l}\text { Nyeri lutut }+ \text { minimal } 1 \\
\text { dari } 3 \text { kriteria berikut : } \\
\text { - Umur }>50 \text { tahun } \\
\text { - Kaku pagi }<30 \text { menit } \\
\text { - Krepitus }\end{array}$ & $\begin{array}{l}\text { Nyeri lutut }+ \text { minimal } 3 \\
\text { dari } 6 \text { kriteria berikut: } \\
\text { - Umur > } 50 \text { tahun } \\
\text { - Kaku pagi < } 30 \text { menit } \\
\text { - Krepitus } \\
\text { - Nyeri tekan } \\
\text { - Pembesaran tulang } \\
\text { - Tidak panas pada } \\
\text { perabaan }\end{array}$ \\
\hline
\end{tabular}


normal

Sumber : Maharani, 2007 \& Ziad, 2013

OSTEOFIT

\section{Pemeriksaan Diagnostik}

Pada penderita OA, dilakukannya pemeriksaan radiografi pada sendi yang terkena sudah cukup untuk memberikan suatu gambaran diagnostik ( Soeroso, 2006 ). Gambaran Radiografi sendi yang menyokong diagnosis OA adalah :

a. Penyempitan celah sendi yang seringkali asimetris ( lebih berat pada bagian yang menanggung beban seperti lutut ).

b. Peningkatan densitas tulang subkondral ( sklerosis ).

c. Kista pada tulang

d. Osteofit pada pinggir sendi

e. Perubahan struktur anatomi sendi. Berdasarkan temuan-temuan radiografis diatas, maka OA dapat diberikan suatu derajat. Kriteria OA berdasarkan temuan radiografis dikenal sebagai kriteria Kellgren dan Lawrence yang membagi OA dimulai dari tingkat ringan hingga tingkat berat. Perlu diingat bahwa pada awal penyakit, gambaran radiografis sendi masih terlihat normal ( Felson, 2006 ). Menurut Kellgren dan Lawrence (1963) secara radiologis Oseoartritis diklasifikasikan sebagai berikut (Ziad, 2013) :

1. Grade 0 : Normal, tidak terdapat gambaran osteoartritis
2. Grade 1 :Ragu-ragu, tanpa osteofit, penyempitan persendian meragukan

3. Grade 2 :Minimal, osteofit sedikit pada tibia dan patella dan permukaan sendi menyempit asimetris.

4. Grade 3 :Moderate, adanya osteofit moderate pada beberapa tempat, permukaan sendi menyempit, dan tampak sklerosis subkondral.

5. Grade 4 :Berat, adanya osteofit yang besar, permukaan sendi menyempit secara komplit, sklerosis subkondral berat, dan kerusakan permukaan sendi.

\section{Pemeriksaan Laboratorium}

Hasil pemeriksaan laboratorium pada OA biasanya tidak banyak berguna. Pemeriksaan darah tepi (hemoglobin, leukosit, laju endap darah) masih dalam batas - batas normal. Pemeriksaan imunologi masih dalam batas - batas normal. Pada OA yang disertai peradangan sendi dapat dijumpai peningkatan ringan sel peradangan ( < 8000 / $\mathrm{m}$ ) dan peningkatan nilai protein.Pemeriksaan imunologi (ANA, faktor rheumatoid, dan komplemen) masih dalam batas-batas normal ( Soeroso 2014)

Penatalaksanaan

Pengobatan yang dapat menyembuhkan OA sampai saat ini belum ditemukan. Pengobatan lebih 
ditujukan pada pengurangan nyeri, menjaga atau mempertahankan mobilitas dan mencegah terjadinya gangguan fungsi, memperbaiki kualitas hidup dan mencegah terjadinya efek toksik dari obat. Tujuan penatalaksanaan pasien yang mengalami osteoartritis adalah untuk edukasi pasien, pengendalian rasa sakit, memperbaiki fungsi sendi yang terserang dan menghambat penyakit supaya tidak menjadi lebih parah. Pengelolaan osteoartritis berdasarkan atas sendi yang terkena dan berat ringannya osteoartritis yang diderita.

Penatalaksanaan osteoartritis terbagi atas 3 hal, yaitu : Terapi non-farmakologis

a. Edukasi atau penjelasan kepada pasien perlu dilakukan agar pasien dapat mengetahui serta memahami tetang penyakit yang dideritanya, bagaimana agar penyakitnya tidak bertambah semakin parah, dan agar persediannya tetap terpakai

b. Terapi fisik atau rehabilitasi

Terapi ini dilakukan untuk melatih pasien agar persendiannya tetap dapat dipakai dan melatih pasien untuk melindungi sendi yang sakit, Penurunan berat badan, Berat badan yang berlebih merupakan faktor yang memperberat osteoartritis. Oleh karena itu, berat badan harus dapat dijaga agar tidak berlebih dan diupayakan untuk melakukan penurunan berat badan apabila berat badan berlebih (Soeroso 2014 \& Karen, 2014). c. Terapi farmakologis

Karena tujuan utama terapi ini untuk mengurangi nyeri secara efektif dengan toksisitas yang rendah, obat topikal sering digunakan sebelum medikasi oral. Di Amerika Serikat, krim capsaicin terbukti ampuh dalam penanganan nyeri OA yang bekerja lokal dengan deplesi neurotransmiter substans P. Ketika menggunakan obat topikal atau hasilnya kurang baik, analgesik murni biasanya dibutuhkan.Asetaminofen adalah terapi farmakologi ssistemik pertama yang direkomendasikan untuk OA lutut dan pinggul oleh The American Collegeof Rheumatology, European League AgainstRheumatism, American Academy of Orthopaedic Surgeons dan organisasi lainnya. Sejumlah besar literatur yang membandingkan asetaminofen dengan plasebo dan dengan NSAID pada jangka lama menunjukkan asetaminofen inferior terhadap NSAID dan secara klinis tidak superior terhadap plasebo untuk mengurangi nyeri OA dalam jangka panjang.Analgesik murni lainnya telah efektif yaitu tramadol, analgesik yang bekerja di sentral, dan analgesik opioid. Namun,keduanya memiliki insidensi yang tinggi terhadap efek samping yang tidak bisa ditoleransi (NICE 2014).

Meski ada kekhawatiran terhadap keamanan dan publisitas terbaru tentang risiko kardiovaskular, NSAID dan 
inhibitor siklo-oksigenase-2(COX-2) tetap menjadi terapi OA; obat ini adalah satu-satunya obat yang secara konsisten telah menunjukkan efek mengurangi nyeri OA dalam jangka panjang. Glukosamin maupun kondroitin sulfat tidak ada yang lebih baik dibandingkan plasebo,COX-2 meringankan nyeri lebih baik dalam 2 tahun. Pemilihan dalam menggunakan NSAID untuk OA harus didasarkan pada beberapa faktor,seperti kecocokan dosis, kenyamanan dokter dan pasien, dan harga. Ketika NSAID digunakan pada pasien risiko kejadian gastrointestinalnya meningkat, dapat ditambahkan proton pumpinhibitor atau misoprositol.(NICE 2014, Bradley2010 ) Pasien yang menggunakanNSAID harus diawasi untuk toksisitas ginjal, khususnya jika pasien lajut usia, dengan hipertensi atau diabetes mellitus.Analgesik oral non opiat pada umumnya telah dicoba pasien untuk mengobati sendiri penyakitnya, terutama dalam hal mengurangi atau menghilangkan rasa sakit dengan membeli obat-obatan yang dijual bebas Analgesik topikal dengan mudah kita dapatkan dipasaran dan banyak sekali yang dijual bebas. Pada umumnya pasien telah mencoba terapi dengan cara ini, sebelum memakai obat-obatan peroral lainnya (Soeroso 2014, Amin Z. 2015.)

Obat Anti Inflamasi Non Steroid (OAINS), Inhibitor COX-2 (Siklooksigenase-2), dan Asetaminofen untuk mengobati rasa nyeri yang timbul pada Osteoartritis, penggunaan OAINS dan inhibitor COX-2 dinilai lebih efektif daripada penggunaan asetaminofen. Namun karena risiko toksisitas OAINS lebih tinggi dari pada asetaminofen, maka tetap menjadi obat pilihan pertama dalam penanganan rasa nyeri pada osteoartritis. Cara lain untuk mengurangi dampak toksisitas dari OAINS adalah dengan cara mengkombinasikannya dengan menggunakan inhibitor COX-2 (NICE 2014. Sudoyo. A.W, 2006 \& Viadamir, 2003).

Diacerin merupakan derivat anthraquinone, obat yang relatif baru, Rhein, merupakan metabolit aktif dari diacerin, menghambat produksi dan aktifitas interleukin-1 beta sebagai sitokin proinflamasi mayor yang yang terlibat pada terjadinya destruksi tulang rawan. Manfaat dari diacerin sebagai symptom modifying effect dan disease modifying effect. Diacerein mempunyai efek anabolik dan anti-katabolic efek pada kartilago:Rhein menstimulasi IGF and TGF $\beta$ (promotes cartilage synthesis) Rhein menghambat produksi dan aktifitas IL-1, IL-6, TNF $\alpha$ menghambat produksi dan aktifitas nitric oxide, menurunkan sintesa NO dan IL-1(Bukard F. 2010).

\section{Terapi Intra-Artikular}

Kortikosteroid 
Injeksi kortikosteroid intraartikular mengurangi nyeri dalam jangka pendek,terutama pada rasa nyeri yang sangat; terapi ini juga berguna untuk mengurangi nyeri yang tidak responsif dengan terapi sistemik optimal.Injeksi intra-artikular pada sendi yang sama lebih dari 3 atau 4 kali setahun tidak dianjurkan karena kekhawatiran efek sampingnya terhadap kartilago artikular dan struktur sendi yang mengelilinginya.

\section{Hialuronan}

Injeksi intra-artikular hialuronan ditujukan sebagai suplementasi viskous karena dimaksudkan untuk meningkatkan viskositas cairan sinovial pada OA untuk mengembalikan keadaan mendekati normal. Namun, karena waktu paruh hialuronan secara in vivo pendek, efek mengurangi nyerinya mungkin hasil dari mekanisme yang dihubungkan dengan nonviskositas. Beberapa hialuronan tersedia untuk penggunaan pada OA lutut. Masing-masing telah bermanfaat mengurangi rasa nyeri yang merupakan hasil dari penggunaan obat ini dalam 6 bulan atau lebih lama. Meskipun kontroversi tetap ada mengenai batasan pengurangan rasa nyeri yang merupakan hasil penggunaan obatini, agak aman dan ditoleransi baik.

\section{Operasi}

Pasien dengan gejala tidak terkontrol secara adekuat dengan terapi medis dan dengan derajat sedang sampai berat dan gangguan fungsional harus dipertimbangkan menjalani operasi, terutama pada lutut atau pinggul yang sendinya bergejala. Implan modern mengurangi nyeri dan telah terbukti dapat tahan lama dan memeperbaiki fungsional. Artroplasti telah terbukti memperbaiki kualitas hidup pasien dengan OA lutut dan pinggul dan merupakan satu dari beberapa penalaksanaan yang maju dalam 30 tahun terakhir.21 Sebagai tambahan pada artroplasty, beragam prosedur digunakan pada OA termasuk debridement artroskopi, artrodesis dan teknik penyusunan kembali sendi. Beberapa pendekatan lain pada terapi OA sedang diteliti oleh industri farmasi dan bioteknologi dan oleh peneliti akademik.

Terapi bedahi ini diberikan apabila terapi farmakologis tidak berhasil untuk mengurangi rasa sakit dan juga untuk melakukan koreksi apabila terjadi deformitas sendi yang mengganggu aktivitas sehari-hari (NICE 2014, Seroso 2014.)

\section{Pengobatan Alternatif Dan}

\section{Komplementer Suplemen Nutrisi}

Pada kebanyakan pasien dengan arthritis telah mencoba pengobatan alternatif dan komplementer(CAM) untuk mengurangi nyerinya.Pada satu penelitian, setidaknya separuh pasiendengan OA lutut telah digunakan sekurangnyasatu macam CAM dalam 20 minggu sebelumnya. Beragam penelitian 
telah dilaporkan memilikibeberapa manfaat dengan penggunaanbanyak CAM ini, termasuk akupunktur dan beberapa suplemen herbal, meski besarnya manfaa trendah Kebanyakan suplemen yang dibicarakan adalahglukosamin dan kondroitin sulfat, yang tetap populer bahkan setelah NIH mensponsori glucosamine/ chondroitin arthritis intervention trial (GAIT) melaporkan tidak ada manfaat yang signifikan dari obat-obatan ini dalam penggunaan 2 tahun baik tunggal maupun kombinasi. Banyak pasien denganOA melanjutkan penggunaan obat ini dan menganggap ini memberi manfaat. Transcutaneous Electrical Nerve Stimulation (TENS) dapat diberikan pada pasien dengan osteoartritis lutut. Sebuah penelitian systematic review yang dilakukan Osiri dkk (2000) menyimpulkan bahwa TENS memiliki kemampuan yang lebih baik dari plasebo untuk melakukan kontrol nyeri pada pasien osteoartritis lutut. Perbaikan kekakuan sendi lutut pada pasien osteoartritis juga ditunjukkan dengan terapi TENS.(Ramsey SD.2010 )

\section{Terapi Okupasi}

Hal ini sering digunakan unutk pasien yang mengalami arthritis inflamasi untuk menyedia-kan penilaian yang dapat membantu aktivitas sehari-hari, berguna pada OA. Terapi okupasi dapat menilai kemampuan fungsional pasien, menyediakan peralatan yang dapat membantu sesuai kebutuhan dan mengajarkan cara melindungi sendi dan kemampuan menjaga energi. Fisioterapist akan menilai kekuatan otot, stabilitas sendi dan keterbatasan fungsi: memberikan rekomendasi penggunaan berbagai modalitas, seperti pemanasan, memberikan program latihan untuk mempertahankan atau memperbaiki luas gerak sendi.meningkatkan kekuatan otot dan menyarankan penggunaan alat bantu seperti cane,crutches, walker untuk meningkatkan mobilitas. ( Amin Z. 2015)

\section{Terapi osteoartritis pada masa mendatang}

Pendekatan terbaru pada terapi osteoarthritis (OA) terus dicari termasuk usaha untuk mengenali DiseaseModifying OA drugs (DMOADs), teknik memperbaiki jaringan untuk rekonstitusi kartilgo dan jaringan sendi, Sasaran terapiDMOAD termasuk langkah pada jalur degradasi kartilago dan pada remodelling tulang yang terkena $\mathrm{OA}$, beragam inhibitor aggrecanase dan protease terlibat pada degradasi tahap awal matriks kartilago pada segala tingkatan perkembangan. Chondroprotective Agent adalah obatobatan yang dapat menjaga atau merangsang perbaikan dari kartilago pada pasien osteoartritis, sebagaimana penelitian menggolongkan obat-obatan ini dalam Slow Acting Osteoarthritis Drugs (SAAODs) atau Disease Modifying Anti 
Drugs (DMOADs). Obat-obatan yang termasuk dalam kelompok obat ini adalah : asam hialuronat, konroitin sulfat, glikosaminoglikan, vitamin $\mathrm{C}$, superoxide dismutase dan sebagainya (Soeroso 2014, NICE 2014 \& Charles, 2016).

Usaha untuk mengembangkan konstruksi kartilago fungsional secara biomekanis menggunakan bera-gam teknologi dalam membangun jaringan, sel punca mesenkim atau kondrosit autolog telah banyak diperhatikan karena aplikasi teknik ini dengan mengisolasi defek kondral dan karena jaringan yang berasal dari mesenkim merupakan sasaran yang baik untuk teknologi sel punca. Namun, seluruh solusi jangka panjang untuk memperbaiki progresi OA mungkin perlu menggabungkan strategi aktif secara biomekanis, karena mengganti struktur sendi yang terdegradasi hanya dengan konstruksi fungsional saja tidak akan mencegah disintegrasi cepat pada adanya tekanan biomekanis yang menyimpang dan sedang berlangsung. Beragam strategi biomekanis sedang diselidiki. Hal ini termasuk usaha untuk membuta tiruan beban pada kaki saat berjalan melalui sepatu yan dimodifikasi,23 mengubah beban lutut medial melalui penggunaan ortotik yang dimasukkan ke dalam sepatu dan penggunaan penahan beban pada lutut.

\section{KESIMPULAN}

Osteoartritis adalah penyakit sendi degeneratif dan inflamasi yang ditandai dengan perubahan patologik pada seluruh struktur sendi. Perubahan patologis yang terjadi meliputi hilangnya tulang rawan sendi hialin, diikuti penebalan dan sklerosis tulang subkondral, pertumbuhan osteofit pada tepi sendi, teregangnya kapsul sendi, sinovitis ringan dan kelemahan otot yang menyokong sendi dan penyakit yang sering dijumpai pada praktek sehari-hari, terutama pada pasien lanjut usia. Diagnosis osteoartritis biasanya didasarkan pada gambaran klinis dan radiografi. pemeriksaan radiografi pada sendi yang terkena sudah cukup untuk memberikan suatu gambaran diagnostik. Gambaran radiografi sendi yang mendukung diagnosis OA adalah:Penyempitan celah sendi yang seringkali asimetris (lebih berat pada bagian yang menanggung beban), peningkatan densitas (sklerosis) tulang subkondral, Osteofit pada pinggir sendi, Perubahan struktur anatomi sendi. Ada beberapa kriteria diagnosis osteoartritis yang dikembangkan oleh para peneliti, namun yang paling populer adalah kriteria diagnosis American College of Rheumatology (ACR).

Tatalaksana

Osteoartritis membutuhkan pendekatan nonfarmakologis dan farmakologis yang dilaksanakan secara sinergis. Terapi nonfarmakologis penting dalam tatalaksana 
osteoartritis untuk mengurangi stress mekanis sehingga memberikan kesempatan tubuh untuk melakukan "self healing" pada jejas sendi. Edukasi adalah faktor penting dalam tatalaksanan nonfarmakologis osteoartritis. Pasien sebaiknya menghindari aktivitas yang menyebabkan pembebanan berlebih pada sendi. Terapi farmakologis osteoartritis dapat diberikan anti-nyeri, Parasetamol, NSAID topikal atau sistemik sampai opioid (tergantung derajad nyeri dan inflamasi). injeksi kortikosteroid dan injeksi hialuronat atau viscosupplement intra-artikuler terutama untuk osteoartritis lutut dengan efusi. Bila NSAID digunakan pada pasien risiko kejadian gastrointestinalnya meningkat, dapat ditambahkan proton pumpinhibitor atau misoprositol.Meski ada kekhawatiran terhadap keamanan dan publisitas terbaru tentang risiko kardiovaskular,NSAID dan inhibitor Siklo-Oksigenase-2 (COX-2) tetap menjadi terapi OA; karena obat ini adalah satu-satunya obat yang secara konsisten telah menunjukkan efek mengurangi nyeri OA dalam jangka panjang.

$$
\text { Secara umum, prognosis }
$$

Osteoartritis adalah baik. Namun, pada Osteoartritis lutut gejala yang berat memiliki prognosis yang kurang baik. Terapi bedah dilakukan jika terapi farmakologis sudah diberikan dan tidak memberikan perbaikan yang signifikan secara klinis. Tindakan bedah yang diindikasikan untuk osteoartritis akut adalah total Joint Arthroplasty.

\section{DAFTAR PUSTAKA}

Altman RD, Hochberg MC, Moskowitz RW, Schmitzer TJ. Recommendations for the Medical Management of Osteoarthritis of the Hip and Knee.Arthritis Rheum 2000;43:1905-15.

Agnes, J. Smink, et al. 2013. Health Care Use of Patients with Osteoarthritis of the Hip or Knee After Implementation of a Stepped Care Strategy : An Observational study. Arthritis Care \& Research. Netherlands.

Amin Zuklkifli L. 2015. Medical review Osteoartritis . MEDICINUS Vol. 28, No. 2 . Ed. Des. 2015.

Bijlsma,JWJ, Lapeber.J. Osteoarthritis: an update with relevance for clinical practice. Lancet vol.377,2011.

Burkhad F. Clinical efficacy and safety of diacerin in osteoarthritis, a review. European muskulosketal review.2010:5(1): 23-9.

Baliunas AJ, Hurwitz DE, Ryals AB, et al. Increased knee joint loads during walking are present in subjects with knee osteoarthritis. Osteoarthritis Cartilage 2002;10:573-579.

Bradley JD, Brandt KD, Katz BP, et al. Comparison of an antiinflammatory dose of ibuprofen, and acetaminophen in the treatment of patients with osteoarthritis of the kneeN Engl J Med 1991;325:87-1

Clegg DO, Reda DJ, Harris CL, et al. Glucosamine, chondroitin sulfate, and the two in combinationforpainful knee osteoarthritis. $\mathrm{N}$ engl J Med 2006;354:795-808. 
Centers for Disease Control and Prevention (CDC). Prevalence of doctordiagnosed rthritis and arthritis-attributable activity limitation-United States, 20032005 [published correction appears in MMWR Morb Mortal Wkly Rep 2006;55:1129]. MMWR Morb Mortal Wkly Rep 2006;55:10891092

Departemen Kesehatan Republik Indonesia Badan Penelitian dan Pengembangan Kesehatan. Laporan Riskesdas 2007 Provinsi Nusa Tenggara Barat..

Dharsono D. Struktur rawan sendi dan perubahannya pada osteoarthritis. Kumpulan makalah temu ilmiah reumatology.Setyohadi B (Ed). IRA. Jakarta 2011.

Erlangga Yusuf, 2012. On How Obesity Links with Osteoarthritis. Gildeprint Drukkerijen, Enschede, The Netherlands.

Felson, D.T., 2008. Osteoarthritis. Dalam : Fauci, A., Hauser, L.S., Jameson, J.L., Ed. HARRISON's Principles of Internal Medicine Seventeenth Edition. New York, United States of America. McGraw-Hill Companies Inc.: 2158-2165.

Felson DT, Anderson JJ, Naimasrk A, Walker AM, Meenan RF. Obesity and knee osteoarthritis. The FraminghamStudy Ann, Intern Med1988;109:18-24.

Guyton \& Hall. 2007. Buku Ajar Fisiologi Kedokteran. Edisi ke-11. Jakarta : EGC.

Hadi S. 2002. Patogenesi osteoartritis. Naskah pertmeuan Ilmiah tahunan VI FK Undipo ( Ed). Padmomartono FS. Badan Penerbit Universitas Diponegoro.Semarang 2002: 277-289.

Hochberg MC, Altman RD, Brandt KD, Clark BM, Dieppe PA, Griffin MR, et al. Guidelines for the medical management of osteoarthritis. Part
1. Osteoarthritis of the hip. Arthritis Rheum 1995;38:1535-40.

Joern, M., Klause, S.B., dan Peer, E. 2010. The Epidemiology, Etiology, Diagnosis, and Treatment of Osteoarthritis of the Knee. Dtsch Arztebl International Didapat dari :http://www.

ncbi.nlm.nih.gov/pmc/articles/PMC 2841860/pdf/Dtsch_Arztebl_Int107-0152.pdf

Kasjmir Y I. Chronic pain in osteoarthritis.(Ed): Pitoyo CW, Nelwan EJ, Salim S. Kumpulan Naskah pertemuan lmiah Nasional X PB PAPDI 2012.Jakarta: 17-21.

Kementerian Kesehatan Republik Indonesia. 2012. Penyakit Tidak Menular.

Kokebie R, Block JA. Managing Osteoarthritis : Current and Future Directions. Medical Progress 2009;36(8):409-415.

Lawrence RC, Felson DT, Helmick CG, et al. Estimates of the prevalence of arthritis and other rheumatic conditions in the United States, part II. Arthritis Rheum 2008;58:26-35.

Lawrence RC, Helmick CG, Arnett FC, Deyo RA, Felson DT, Giannini $\mathrm{EH}$, et al. Estimates of the prevalence of arthritis and selected musculoskeletal disorders in the United States. Arthritis Rheum 1998;41:778-99.

National Collaborating Center for Chronic Conditions. Osteoarthritis. The Care and Management of Osteoarthritis in Adults. NICE. London. 2008.

NICE 2014 Osteoarthritis Care and management in adults Issued: February 2014 NICE clinical guideline 177 guidance.nice.org.uk/cg177.

Poitras S, Avouac J, Rossignol M, et al. A critical appraisal of guidelines for the managementof knee osteoarthritis using Appraisal of 
Guidelines Research and Evaluation criteria.Arthritis Res Ther 2007;9:R126.

Recommendation For The Medical Management of Osteoarthritis of The Hip and Knee. American College of Rheumatology Subcommitee on Osteoarthritis Guidelines. Arthritis Rheum. 2000 Sep; 43(9): 1905 - 15.

Reid D, Potts G, Burnett M, Konnings B. 2014. Physiotherapy management of knee and hip osteoarthritis: a survey of patient and medical practitioners' expectations, experiences and perceptions of effectiveness of treatment. New Zealand Journal of Physiotherapy.

Ramsey SD, Spencer AC, Topolski TD, et al. Use of alternative therapies by older adults withosteoarthritis. Arthritis Rheum 2001;45:222-227.

Sudoyo, A.W. 2006. Buku Ajar Ilmu Penyakit Dalam, Jilid III, Edisi ke4. Jakarta : EGC

Soeroso, J., Isbagio, H., Broto, R., dan Pramudiyo, R., 2014. Osteoartritis. (ed.) Setiati, S, Alwi, I., Sudoyo, A.W.Simadibrata $\mathrm{KM}$, Setyohadi,Bsyam AF. Dalam Buku Ajar Ilmu Penyakit Dalam Jilid III Edisi VI. Jakarta, Indonesia : Penerbit FKUI Pusat.2014; 31973209.

Setyohadi B. Neyri tulang. (ed). Setiati S, Alwi I., Sudoyo A.W.Simadibrata KM, Setyohadi B,Syam AF. Dalam Buku Ajar Ilmu Penyakit Dalam Jilid III Edisi VI. Jakarta, Indonesia : Penerbit FKUI Pusat.2014;312729. 